\title{
COOPERATION AND HUMAN DEVELOPMENT: THE EMERGING AGENDA FORTHE NEW MILLENNIUM
}

\author{
Júlia Trevisan Martins ${ }^{1}$ \\ Maria Lúcia do Carmo Cruz Robazzi²
}

Martins JT, Robazzi MLCC. Cooperation and human development: the emerging agenda for the new millennium. Rev Latino-am Enfermagem 2007 setembro-outubro; 15(número especial):874.

The book "Cooperação e desenvolvimento humano: a agenda emergente para o novo milênio" [Cooperation and human development: the emerging agenda for the new millennium], written by Carlos Lopes, was published in Portuguese in 2005, by UNESP publishers, Brazil. The author is Guinean, from Canchungo. He is a sociologist and PhD in History by the University of Paris, Pantheon-Sorbonne. The author is a representative of the United Nations and of the United Nations Program for Human Development.

The book is presented in four chapters and focuses on the need for a broad political debate to draw up an agenda for social change and development, so as to reduce poverty in the globalized world. It stresses that the world, in addition to factors referred to as classic, such as land, capital, work and knowledge, needs to advance through solidarity in order to produce significant changes in the form of information and knowledge acquisition and diffusion, and, thus, share what one has and knows. It also points out that policies should take into consideration the different identities and cultures, and should be employed as strategies for sustainable development.

For the author, the world does not live a civilization clash, but rather experiences a different and plural living. This means openness to diversity and cultural freedom, obtained through effective morality and ethics, understood as the ability to accept differences and view them as enriching, developing the practice of political communication and understanding one's role to encourage new social transformations. The globalized planet has a complex cultural diversity; it is important to believe that human civilization is distinct and plural, that cultural freedom is fundamental, since it reduces the exclusion that can result.
The author considers that the development of human ability is a process of international help, respecting cultural differences, that it is possible when individual as well as social chances are offered and created, and that poverty does not only refer to low income, but to a mixture of combinations. Strategies should be broad, holistic and focus on the long term. Donations at the moment of catastrophes help, but do not eradicate poverty. Societies should seek institutional interventions that aim at developing and exchanging knowledge in view of the benefit of all those involved. Among the alternatives for less developed countries, Lopes considers that these nations should undertake the process of developing their abilities; they should change from passive receivers to having an active role in the construction of abilities associated with commerce, and commercial negotiations should be established under the aegis of ethics and justice.

He concludes that globalization is a process of risks and chances created in association with the ability to include and take advantage of the global economy, characterized by dealing with new situations and by the polarization of different natures. Moreover, the lack of preparation to deal with this new world can contribute to new forms of exclusion. Hence, the essence for human development is understood as a constant expansion of both individual and social opportunities, highlighting the protection of each and every person's cultural freedom.

Recebido em: 29.1.2007 Aprovado em: 20.8.2007

${ }^{1}$ Professor of the Undergraduate Nursing Course, Londrina State University, Brazil, Doctoral Student of the Iter-units program, e-mail: jtmartins@uel.br; ${ }^{2}$ Full Professor, e-mail: avrrmlccr@eerp.usp.br. University of São Paulo at Ribeirão Preto, College of Nursing, WHO Collaborating Center for Nursing Research Development, Brazil 